\title{
Mycobacterium pulveris sp. nov., a Nonphotochromogenic Mycobacterium with an Intermediate Growth Rate
}

\author{
MICHIO TSUKAMURA, * SHOJI MIZUNO, AND HARUO TOYAMA \\ The National Chubu Hospital, Obu, Aichi, Japan 474
}

\begin{abstract}
A group of nonphotochromogenic mycobacteria with intermediate growth rates were isolated from house dust and were considered to be members of a new species in the genus Mycobacterium. This organism is named Mycobacterium pulveris sp. nov. The type strain is NCH (National Chubu Hospital) 33505 (= ATCC 35154).
\end{abstract}

In the course of an ecological study of the mycobacteria that occur in house dusts, a group of nonphotochromogenic mycobacteria with intermediate growth rates were isolated, and these organisms were considered to be members of a species. These strains were isolated from five houses in Obu, Aichi Prefecture, Japan. We have named this organism Mycobacterium pulveris sp. nov. In this paper we describe this organism.

\section{MATERIALS AND METHODS}

Isolation of strains. The method used for isolating mycobacterial strains from house dust has been described previously (13). From colonies growing on isolation medium (Ogawa egg medium), only nonphotochromogenic colonies were selected. Each colony was subcultured on Ogawa egg medium slants and purified by single-colony isolation. A total of 104 characters were studied for each isolate. The characters and tests used have been described previously $(6$, $10)$.

Numerical taxonomy study. The isolates obtained from house dust were compared with all named mycobacterial species except Mycobacterium leprae and Mycobacterium lepraemurium. For comparisons with rapidly growing mycobacteria, 104 characters were used; for comparisons with slowly growing mycobacteria, 76 of these 104 characters were used. The results of each test were coded as either 1 (positive) or 0 (negative). The matching coefficient ( $M$ value) between two strains was estimated by using the following equation: $\mathrm{M}$ value $=\left(n_{s} \times 100\right) /\left(n_{s}+n_{d}\right)$, where $n_{s}$ is the number of characters which have similar code symbols and $n_{d}$ is the number of characters which have different code symbols.

A comparison of house dust strains with named species was made by using a numerical taxonomy method in which the range of a species was determined as $X \pm 2 s$ (7), where $X$ is the mean of $M$ values estimated for the strains of a species compared with the hypothetical median organism pattern (HMO) (2) of the species and $s$ is the standard deviation. The range $X \pm 2 s$ contains about $95 \%$ of the strains of a species (7). The ranges of the named species were determined from the data of previous studies $(10,12$, 14).

The $\mathbf{M}$ values of the isolates which we examined were compared with the HMOs of all named species. If our isolates belonged to any named species, the $M$ values of these isolates compared with the HMO of the named species would have been included in the range of the named species. On the other hand, if the isolates did not belong to any named species, the $M$ values would have fallen outside that range (7).

\section{RESULTS AND DISCUSSION}

About 500 nonphotochromogenic isolates were studied, and the majority of these belonged to named species; however, 8 isolates obtained from five houses were similar to each other and were considered to be members of the new species described here. A numerical analysis of the taxonomic position of the isolates showed that they do not belong to any previously described mycobacterial species (Tables 1 and 2). The mycobacteria which were relatively similar in the numerical taxonomy study were $\mathrm{Myco}$ bacterium chitae, Mycobacterium thermoresistibile, Mycobacterium flavescens, Mycobacterium nonchromogenicum, Mycobacterium avium, Mycobacterium intracellulare, and $M y$ cobacterium scrofulaceum. Characteristics which differentiated our strains from these mycobacteria are shown in Tables 3 and 4.

Mycobacterium pulveris sp. nov. (pul'ver.is. L. gen. $\mathrm{n}$. pulvis dust referring to the source, house dusts). The description below is based on eight strains.

Cells are acid-fast short rods or coccoid forms less than $2 \mu \mathrm{m}$ long and about $0.5 \mu \mathrm{m}$ wide. Mycelia or branching forms are not produced in initial growth on Ogawa egg medium (6). Aryl- 
TABLE 1. Differentiation of $M$. pulveris from species of slowly growing mycobacteria on the basis of numerical taxonomy

\begin{tabular}{|c|c|c|c|c|}
\hline Species & $\begin{array}{l}\text { No. of } \\
\text { strains } \\
\text { tested }\end{array}$ & $\begin{array}{l}\mathrm{M} \text { values }(\%) \text { for } \\
\text { strains compared } \\
\text { with the HMO of } \\
\text { the species }\end{array}$ & $\begin{array}{c}\text { Lower limit } \\
\text { of the range } \\
\text { of } \mathrm{M} \text { values } \\
(\%)^{a}\end{array}$ & $\begin{array}{c}\text { M values }(\%) \text { for eight } \\
\text { strains of } M \text {. pulveris } \\
\text { compared with the } \\
\text { HMO of the other } \\
\text { species }\end{array}$ \\
\hline M. africanum & 5 & $97.4 \pm 0.89^{b}$ & 96 & $58.1 \pm 5.11^{b}$ \\
\hline M. asiaticum & 5 & $95.4 \pm 2.51$ & 91 & $68.5 \pm 4.21$ \\
\hline M. avium & 18 & $94.2 \pm 2.73$ & 89 & $72.8 \pm 2.82$ \\
\hline M. bovis & 7 & $96.7 \pm 1.60$ & 94 & $59.6 \pm 5.01$ \\
\hline M. gastri & 8 & $95.4 \pm 1.30$ & 93 & $71.1 \pm 3.14$ \\
\hline M. gordonae & 11 & $94.9 \pm 2.07$ & 91 & $69.9 \pm 3.27$ \\
\hline M. haemophilum & 4 & $96.3 \pm 3.40$ & 90 & $64.8 \pm 3.54$ \\
\hline M. intracellulare & 40 & $91.5 \pm 3.41$ & 85 & $76.0 \pm 2.78$ \\
\hline M. kansasii & 16 & $92.8 \pm 2.52$ & 88 & $72.5 \pm 2.51$ \\
\hline M. malmoense & 10 & $95.1 \pm 2.28$ & 91 & $66.0 \pm 2.73$ \\
\hline M. marinum & 21 & $94.0 \pm 3.25$ & 88 & $70.1 \pm 2.30$ \\
\hline M. microti & 5 & $97.0 \pm 1.87$ & 94 & $60.1 \pm 4.32$ \\
\hline M. nonchromogenicum & 7 & $95.1 \pm 2.97$ & 90 & $75.0 \pm 2.39$ \\
\hline M. scrofulaceum & 10 & $93.0 \pm 1.49$ & 91 & $73.5 \pm 2.00$ \\
\hline M. shimoidei & 5 & $99.0 \pm 1.22$ & 97 & $65.1 \pm 2.95$ \\
\hline M. simiae & 5 & $98.6 \pm 1.52$ & 96 & $67.0 \pm 4.17$ \\
\hline M. szulgai & 8 & $96.0 \pm 0.93$ & 95 & $67.5 \pm 1.60$ \\
\hline M. terrae & 9 & $94.8 \pm 2.64$ & 90 & $70.0 \pm 2.56$ \\
\hline M. triviale & 10 & $94.5 \pm 2.07$ & 91 & $64.3 \pm 2.49$ \\
\hline M. tuberculosis & 4 & $96.5 \pm 0.58$ & 96 & $61.1 \pm 3.91$ \\
\hline M. ulcerans & 5 & $96.8 \pm 1.48$ & 94 & $56.4 \pm 3.54$ \\
\hline M. xenopi & 10 & $94.9 \pm 3.03$ & 89 & $63.0 \pm 2.39$ \\
\hline M. pulveris & 8 & $92.5 \pm 4.24$ & 84 & $92.5 \pm 4.24$ \\
\hline
\end{tabular}

a Calculated by subtracting 2 standard deviations from the mean. About $95 \%$ of the strains of each species should have $\mathrm{M}$ values higher than the lower limit.

${ }^{b}$ Mean \pm standard deviation.

sulfatase activity is positive after 14 days. These characteristics indicate that the strains belong to the genus Mycobacterium (3).

With one loopful $(0.1 \mathrm{mg}$, wet weight) of inoculum, all strains show abundant growth on Ogawa egg medium after incubation at $37^{\circ} \mathrm{C}$ for 5 days. One strain grows after 3 days. Thus, the growth rate is faster than that of slowly growing mycobacteria and slower than that of rapidly growing mycobacteria. When plated onto Ogawa egg medium as single cells, the organisms grow as colonies after 7 to 8 days. When they are isolated, the strains are susceptible to $0.2 \%$ picric acid in modified Sauton agar medium ( $\mathrm{pH}$ 7.0) (6), but after a few transfers on Ogawa egg medium, they grow on this medium. Strains do not utilize succinate, malate, or fumarate as a sole source of carbon in the presence of ammoniacal nitrogen. The characteristics given above are similar to those of slowly growing mycobacteria $(4,5,8,9,11)$. However, our isolates are resistant to $0.2 \%$ sodium nitrite in modified Sauton agar medium and to $5 \% \mathrm{NaCl}$ in Ogawa egg medium. These characteristics are similar to those of rapidly growing mycobacteria $(4,5,8,9,11)$. Thus, we consider our isolates to be intermediate between slowly growing and rapidly growing mycobacteria.

Growth is produced on Ogawa egg medium or Löwenstein-Jensen medium at 28,37 , and $42^{\circ} \mathrm{C}$, but only three of eight strains grow at $45^{\circ} \mathrm{C}$. Colonies on Ogawa egg medium are wet, smooth, creamy, and nonphotochromogenic. Colonies on modified Sauton agar medium (with glutamate substituted for asparagine) are wet, smooth, and creamy or slightly yellowish.

All strains are resistant to hydroxylamine hydrochloride $(125 \mu \mathrm{g} / \mathrm{ml})$, ethambutol $(5 \mu \mathrm{g} / \mathrm{ml})$, rifampin $(25 \mu \mathrm{g} / \mathrm{ml})$, isoniazid $(10 \mu \mathrm{g} / \mathrm{ml})$, sodium chloride $(5 \%), p$-nitrobenzoic acid $(0.5 \mathrm{mg} / \mathrm{ml})$, sodium salicylate $(0.5 \mathrm{mg} / \mathrm{ml})$, and thiophene-2carboxylic acid hydrazide $(1 \mu \mathrm{g} / \mathrm{ml})$ in Ogawa egg medium; all strains are susceptible to hydroxylamine hydrochloride $(250 \mu \mathrm{g} / \mathrm{ml})$, mitomycin C $(5 \mu \mathrm{g} / \mathrm{ml})$, and 5 -fluorouracil $(20 \mu \mathrm{g} / \mathrm{ml})$ in Ogawa egg medium.

Niacin is not produced; $p$-aminosalicylate and salicylate are not degraded to catechol; arylsulfatase activity is negative after 3 days but positive after 14 days; catalase activity (semiquantitative) is negative (foam height, less than 45 $\mathrm{mm}) ; \beta$-esterase is produced; nicotinamidase and pyrazinamidase tests are positive. Urease activity is positive in two of eight strains. Aceta- 
TABLE 2. Differentiation of $M$. pulveris from species of rapidly growing mycobacteria on the basis of numerical taxonomy

\begin{tabular}{|c|c|c|c|c|}
\hline Taxon & $\begin{array}{l}\text { No. of } \\
\text { strains } \\
\text { tested }\end{array}$ & $\begin{array}{l}M \text { values }(\%) \text { for } \\
\text { strains compared } \\
\text { with the HMO of } \\
\text { the species }\end{array}$ & $\begin{array}{c}\text { Lower limit } \\
\text { of the range } \\
\text { of } \mathrm{M} \text { values } \\
(\%)^{a}\end{array}$ & $\begin{array}{l}\text { M values }(\%) \text { for eight } \\
\text { strains of } M \text {. pulveris } \\
\text { compared with the } \\
\text { HMO of the species }\end{array}$ \\
\hline \multicolumn{5}{|l|}{ Nonphotochromogenic mycobacteria } \\
\hline M. agri & 29 & $96.3 \pm 2.45^{b}$ & 91 & $71.4 \pm 1.41^{b}$ \\
\hline M. chelonei subsp. abscessus & 14 & $94.3 \pm 3.02$ & 88 & $67.6 \pm 2.50$ \\
\hline M. chelonei subsp. chelonei & 12 & $91.1 \pm 3.42$ & 84 & $69.9 \pm 2.03$ \\
\hline M. chitae & 4 & $98.3 \pm 1.26$ & 96 & $83.1 \pm 2.03$ \\
\hline M. diernhoferi & 5 & $97.2 \pm 1.79$ & 93 & $74.4 \pm 3.20$ \\
\hline M. farcinogenes NCTC $10955^{\mathrm{T}} \mathrm{C}$ & 1 & & & $68.3 \pm 3.11$ \\
\hline M. fortuitum & 78 & $93.3 \pm 2.60$ & 88 & $62.6 \pm 2.88$ \\
\hline$M$. sengalense NCTC $10956^{\mathrm{T}}$ & 1 & & & $59.6 \pm 1.60$ \\
\hline M. smegmatis "subsp. lacticola"d & 5 & $98.0 \pm 0.71$ & 96 & $52.6 \pm 2.82$ \\
\hline M. smegmatis "subsp. smegmatis"d & 15 & $96.8 \pm 2.04$ & 92 & $52.0 \pm 3.70$ \\
\hline \multicolumn{5}{|l|}{ Scotochromogenic mycobacteria } \\
\hline M. aichiense & 5 & $95.6 \pm 3.21$ & 89 & $67.4 \pm 3.16$ \\
\hline M. aurum & 35 & $90.8 \pm 4.57$ & 81 & $60.5 \pm 3.59$ \\
\hline M. austroafricanum & 23 & $97.3 \pm 1.71$ & 94 & $72.0 \pm 4.14$ \\
\hline M. chubuense & 5 & $96.0 \pm 4.69$ & 86 & $73.4 \pm 2.88$ \\
\hline M. gadium & 4 & $98.0 \pm 0.82$ & 96 & $71.9 \pm 2.23$ \\
\hline M. duvalii & 4 & $97.0 \pm 2.16$ & 92 & $70.9 \pm 3.23$ \\
\hline$M$. flavescens $\mathrm{I}^{e}$ & 9 & $96.6 \pm 2.19$ & 92 & $76.1 \pm 4.64$ \\
\hline M. flavescens $\mathrm{II}^{e}$ & 21 & $96.0 \pm 2.15$ & 91 & $74.9 \pm 1.81$ \\
\hline M. gilvum & 3 & $94.3 \pm 3.79$ & 86 & $72.1 \pm 4.49$ \\
\hline M. komossense & 3 & $98.3 \pm 1.53$ & 95 & $64.1 \pm 3.91$ \\
\hline$M$. neoaurum & 19 & $95.0 \pm 2.13$ & 90 & $60.4 \pm 4.07$ \\
\hline M. obuense & 4 & $95.0 \pm 2.58$ & 90 & $60.3 \pm 3.37$ \\
\hline$M$. parafortuitum & 12 & $88.0 \pm 4.11$ & 79 & $70.3 \pm 4.00$ \\
\hline M. phlei & 11 & $91.9 \pm 3.05$ & 86 & $67.8 \pm 3.37$ \\
\hline M. rhodesiae & 6 & $97.0 \pm 2.68$ & 91 & $66.8 \pm 4.56$ \\
\hline M. sphagni & 3 & $98.0 \pm 1.00$ & 96 & $69.9 \pm 1.64$ \\
\hline$M$. thermoresistibile & 14 & $97.9 \pm 0.92$ & 96 & $79.6 \pm 1.51$ \\
\hline M. tokaiense & 3 & $97.0 \pm 1.73$ & 93 & $58.4 \pm 2.39$ \\
\hline M. vaccae & 6 & $94.3 \pm 1.37$ & 91 & $62.8 \pm 1.75$ \\
\hline M. pulveris & 8 & $92.3 \pm 4.00$ & 84 & $92.3 \pm 4.00$ \\
\hline
\end{tabular}

${ }^{a}$ Calculated by subtracting 2 standard deviations from the mean. About $95 \%$ of the strains of each species should have $M$ values higher than the lower limit.

${ }^{b}$ Mean \pm standard deviation.

${ }^{\mathrm{c}} \mathrm{T}=$ type strain.

${ }^{d}$ See reference 10 .

e See reference 14.

midase, benzamidase, isonicotinamidase, salicylamidase, allantoinase, and succinamidase activities are negative.

Glutamate is utilized, but serine, glucosamine, acetamide, benzamide, monoethanolamine, and trimethyelene diamine are not utilized as simultaneous nitrogen and carbon sources.

Acetate and pyruvate are utilized, but citrate, succinate, malate, malonate, benzoate, and fumarate are not utilized as sole carbon sources in the presence of ammoniacal nitrogen.

Glucose and $n$-propanol are utilized, but fructose, sucrose, mannose, galactose, arabinose, xylose, rhamnose, trehalose, inositol, mannitol, sorbitol, ethanol, propylene glycol, 1,3-butylene glycol, 1,4-butylene glycol, 2,3-butylene glycol, $n$-butanol, and isobutanol are not utilized as sole carbon sources in the presence of ammoniacal nitrogen.

Serine, acetamide, urea, pyrazinamide, nicotinamide, and nitrate are utilized, but benzamide and nitrite are not utilized as sole sources of nitrogen in the presence of glycerol carbon.

Additional characteristics are shown in Tables 3 and 4.

Of characteristics that are variable among strains within the species, the type strain produces no growth at $45^{\circ} \mathrm{C}$, is tolerant to $0.1 \%$ sodium salicylate in modified Sauton agar medium, produces $\beta$-galactosidase and urease activities, does not utilize mannose as a sole source of carbon, and grows at $37^{\circ} \mathrm{C}$ after 5 days.

The type strain is strain $\mathrm{NCH}$ (National Chubu Hospital) 33505 (= ATCC 35154). 
TABLE 3. Characters useful for differentiating $M$. pulveris from $M$. intracellulare, $M$. avium, $M$. scrofulaceum, and $M$. nonchromogenicum

\begin{tabular}{|c|c|c|c|c|c|}
\hline \multirow[b]{2}{*}{ Character } & \multicolumn{5}{|c|}{$\%$ of strains showing positive reaction } \\
\hline & $\begin{array}{l}\text { M. pulveris } \\
(n=8)\end{array}$ & $\begin{array}{l}M . \text { intra- } \\
\text { cellulare } \\
(n=40)\end{array}$ & $\begin{array}{l}\text { M. avium } \\
(n=18)\end{array}$ & $\begin{array}{l}\text { M. scrofu- } \\
\text { laceum } \\
(n=10)\end{array}$ & $\begin{array}{c}\text { M. nonchromo } \\
\text { genicum } \\
(n=7)\end{array}$ \\
\hline Long rods $(>7 \mu \mathrm{m})$ & 0 & 0 & 0 & 0 & 86 \\
\hline Growth at $45^{\circ} \mathrm{C}$ & 38 & 50 & 72 & 0 & 0 \\
\hline $\begin{array}{l}\text { Resistance to } 250 \mu \mathrm{g} \text { of } \mathrm{NH}_{2} \mathrm{OH} \cdot \mathrm{HCl} \text { per } \mathrm{ml} \\
\quad(\text { Ogawa egg medium) }\end{array}$ & 0 & 100 & 100 & 100 & 100 \\
\hline $\begin{array}{l}\text { Resistance to } 500 \mu \mathrm{g} \text { of } \mathrm{NH}_{2} \mathrm{OH} \cdot \mathrm{HCl} \text { per ml } \\
\quad \text { (Ogawa egg medium) }\end{array}$ & 0 & 88 & 100 & 100 & 100 \\
\hline $\begin{array}{l}\text { Tolerance to } 0.1 \% \text { sodium salicylate (Sauton } \\
\text { agar medium) }\end{array}$ & 75 & 13 & 11 & 40 & 0 \\
\hline $\begin{array}{l}\text { Tolerance to } 0.1 \% \mathrm{NaNO}_{2} \text { (Sauton agar } \\
\text { medium) }\end{array}$ & 100 & 10 & 0 & 0 & 100 \\
\hline $\begin{array}{l}\text { Tolerance to } 0.2 \% \mathrm{NaNO}_{2} \text { (Sauton agar } \\
\text { medium) }\end{array}$ & 100 & 0 & 0 & 0 & 100 \\
\hline $\begin{array}{l}\text { Resistance to } 5 \mu \mathrm{g} \text { of ethambutol per ml } \\
\text { (Ogawa egg medium) }\end{array}$ & 88 & 80 & 100 & 70 & 0 \\
\hline Tween hydrolysis ( 7 days) & 100 & 0 & 0 & 0 & 57 \\
\hline Tween hydrolysis (14 days) & 100 & 8 & 17 & 0 & 100 \\
\hline$\alpha$-Esterase & 100 & 100 & 100 & 90 & 0 \\
\hline$\beta$-Galactosidase & 63 & 0 & 0 & 0 & 86 \\
\hline Nitrate reduction $(6 \mathrm{~h})$ & 100 & 0 & 0 & 0 & 0 \\
\hline Nitrate reduction $(24 \mathrm{~h})$ & 100 & 8 & 0 & 0 & 86 \\
\hline $\begin{array}{l}\text { Glutamate used as simultaneous } \mathrm{N} \text { and } \mathrm{C} \\
\text { sources }\end{array}$ & 100 & 23 & 6 & 0 & 0 \\
\hline $\begin{array}{l}\text { Glucose used as } \mathrm{C} \text { source (ammoniacal } \\
\text { nitrogen) }\end{array}$ & 100 & 83 & 44 & 100 & 0 \\
\hline $\begin{array}{l}n \text {-Propanol used as C source (ammoniacal } \\
\text { nitrogen) }\end{array}$ & 100 & 80 & 50 & 70 & 14 \\
\hline
\end{tabular}

TABLE 4. Characters useful for differentiating $M$. pulveris from $M$. chitae, $M$. thermoresistibile, $M$. flavescens

\begin{tabular}{|c|c|c|c|c|c|}
\hline \multirow[b]{2}{*}{ Character } & \multicolumn{5}{|c|}{$\%$ of strains showing positive reaction } \\
\hline & $\begin{array}{l}\text { M. pulveris } \\
\quad(n=8)\end{array}$ & $\begin{array}{l}\text { M. chitae } \\
(n=4)\end{array}$ & $\begin{array}{l}\text { M. thermo- } \\
\text { resistibile } \\
(n=14)\end{array}$ & $\begin{array}{l}\text { M. flav- } \\
\text { escens I } \\
(n=9)\end{array}$ & $\begin{array}{l}\text { M. flav- } \\
\text { escens II } \\
(n=21)\end{array}$ \\
\hline Growth after 3 days & 13 & 100 & $100^{a}$ & $100^{a}$ & $100^{a}$ \\
\hline Colony pigmentation in the dark & 0 & 0 & 100 & 100 & 100 \\
\hline Growth at $45^{\circ} \mathrm{C}$ & 38 & 0 & 100 & 78 & 43 \\
\hline Growth at $52^{\circ} \mathrm{C}$ & 0 & 0 & 100 & 0 & 0 \\
\hline $\begin{array}{l}\text { Resistance to } 250 \mu \mathrm{g} \text { of } \mathrm{NH}_{2} \mathrm{OH} \cdot \mathrm{HCl} \text { per } \mathrm{ml} \text { (Ogawa } \\
\text { egg medium) }\end{array}$ & 0 & 100 & 0 & 0 & 5 \\
\hline $\begin{array}{l}\text { Tolerance to } 0.1 \% \text { sodium salicylate (Sauton agar } \\
\text { medium) }\end{array}$ & 75 & 0 & 100 & 0 & 0 \\
\hline Arylsulfatase (14 days) & 88 & 100 & 0 & 100 & 100 \\
\hline Tween 80 hydrolysis ( 7 days) & 88 & 100 & 0 & 0 & 0 \\
\hline$\beta$-Galactosidase & 63 & 0 & 0 & 0 & 5 \\
\hline Acid phosphatase $(3 \mathrm{~h})$ & 100 & 100 & 100 & 0 & 0 \\
\hline Urease & 25 & 100 & 100 & 44 & 100 \\
\hline Nicotinamidase & 100 & 100 & 100 & 11 & 86 \\
\hline Acetamide used as simultaneous $\mathrm{N}$ and $\mathrm{C}$ sources & 0 & 100 & 0 & 0 & 0 \\
\hline \multicolumn{6}{|l|}{ Succinate used as sole $\mathrm{C}$ source (ammoniacal } \\
\hline nitrogen) & 0 & 75 & 71 & 0 & 0 \\
\hline Malate used as sole $\mathrm{C}$ source (ammoniacal nitrogen) & 0 & 50 & 100 & 0 & 0 \\
\hline \multicolumn{6}{|l|}{ Fumarate used as sole $\mathrm{C}$ source (ammoniacal } \\
\hline nitrogen) & 0 & 0 & 79 & 0 & 0 \\
\hline $\begin{array}{l}\text { n-Propanol used as sole C source (ammoniacal } \\
\text { nitrogen) }\end{array}$ & 100 & 50 & 100 & 100 & 0 \\
\hline $\begin{array}{l}\text { 1,4-Butylene glycol used as sole } \mathrm{C} \text { source } \\
\text { (ammoniacal nitrogen) }\end{array}$ & 0 & 0 & 0 & 100 & 95 \\
\hline $\begin{array}{l}\text { Mannose used as sole C source (ammoniacal } \\
\text { nitrogen) }\end{array}$ & 13 & 0 & 0 & 100 & 100 \\
\hline
\end{tabular}

\footnotetext{
${ }^{a}$ Slight growth.
} 


\section{LITERATURE CITED}

1. Kestle, D. G., V. D. Abbott, and G. P. Kubica. 1967 Differential identification of mycobacteria. II. Subgroups of groups II and III (Runyon) with different clinical significance. Am. Rev. Respir. Dis. 95:1041-1052.

2. Liston, J., W. Wiebe, and R. R. Colwell. 1963. Quantitative approach to the study of bacterial species. J. Bacteriol. 85:1061-1070.

3. Runyon, E. H., L. G. Wayne, and G. P. Kubica. 1974. Family II. Mycobacteriaceac Chester 1897, 63, p. 681701. In R. E. Buchanan and N. E. Gibbons (ed.), Bergey's manual of determinative bacteriology, 8th ed. The Williams \& Wilkins Co., Baltimore.

4. Tsukamura, M. 1965. Differentiation of mycobacteria by picric acid tolerance. Am. Rev. Respir. Dis. 92:491-492.

5. Tsukamura, M. 1966. Adansonian classification of mycobacteria. J. Gen. Microbiol. 45:253-273.

6. Tsukamura, M. 1975 . Identification of mycobacteria. The National Chubu Hospital, Obu, Aichi, Japan.

7. Tsukamura, M. 1976. An approach to numerical identification of bacterial species. J. Gen. Microbiol. 95:207-212.

8. Tsukamura, M. 1976. Numerical classification of slowly growing mycobacteria. Int. J. Syst. Bacteriol. 26:409-420.

9. Tsukamura, M. 1980 . Usefulness of picric acid-Sauton agar medium for differentiating slowly growing mycobacteria from rapidly growing mycobacteria. Tubercle 61:3335 .
10. Tsukamura, M. 1981. Numerical analysis of rapidly growing, nonphotochromogenic mycobacteria, including $M y$ cobacterium agri (Tsukamura 1972) sp. nov., nom. rev. Int. J. Syst. Bacteriol. 31:247-258.

11. Tsukamura, M. 1981. A review of the methods of identification and differentiation of mycobacteria. Rev. Infect. Dis. 3:841-861.

12. Tsukamura, M. 1983. Numerical classification of 280 strains of slowly growing mycobacteria. Proposal of $M y$ cobacterium tuberculosis series, Mycobacterium avium series, and Mycobacterium nonchromogenicum series. Microbiol. Immunol. 27:325-344.

13. Tsukamura, M., S. Mizuno, H. Murata, H. Nemoto, and H. Yugi. 1974. A comparative study of mycobacteria from patients' room dusts and from sputa of tuberculous patients. Source of pathogenic mycobacteria occurring in the sputa of tuberculous patients as casual isolates. Jpn. J. Microbiol. 18:271-277.

14. Tsukamura, M., S. Mizuno, S. Tsukamura. 1981. Numerical analysis of rapidly growing, scotochromogenic mycobacteria, including Mycobacterium obuense sp. nov., nom. rev., Mycobacterium rhodesiae sp. nov., nom. rev., Mycobacterium aichiense sp. nov., nom. rev., Mycobacterium chubuense sp. nov., nom. rev., and Mycobacterium tokaiense sp. nov., nom. rev. Int. J. Syst. Bacteriol. 31:263-275. 